\title{
A Review on The Significance of Ratricharya (Night Regimen) In The Promotion of Health.
}

\author{
${ }^{1}$ Dr.Bharath.M.S, ${ }^{2}$ Dr.Dhruva Prasad.S, ${ }^{3}$ Dr.Sudhakar P Reddy \\ ${ }^{1}$ Final year PG Scholar, Dept. of PG studies in Swasthavritta, JSSAMC, Mysuru \\ ${ }^{2}$ Second year PG Scholar, Dept. of PG studies in Swasthavritta, JSSAMC, Mysuru \\ ${ }^{3}$ Professor and HOD, Dept. of PG studies in Swasthavritta, JSSAMC, Mysuru
}

\begin{abstract}
:
The most important goal of human life is to attain the state of perfect health, health is not the absence of disease, and it is the harmonious balance of physical, mental and social well-being. Thus to attain the state of perfect well-being, one has to practice healthy regimen like dinacharya (daily regimen), ritucharya (seasonal regimen) and ratricharya (night regimen).In this $21^{\text {st }}$ century people are working continuously day and night which could have serious implications on their health and well-being. The concept of ratricharya (night regimen) is very important for the promotion of health. By following the regimen of Swasthavritta (which includes dinacharya, ratricharya, ritucharya and sadvritta) one can live for hundred years without any disease or illness.
\end{abstract}

Keywords: Health, Ratricharya, Ahara, Nidra, Sleep.

\section{INTRODUCTION:}

Health is an important component of human life. Health is defined as the condition of being sound in body mind of spirit, especially freedom from physical diseases or pain. Health in the broad sense of the world does not merely mean the absence of disease or provision of diagnostic, curative and preventive services. It also includes as embodied in the WHO defines a state of physical mental and social well-being. The harmonious balance of this state of the human individual integrated into his environment constitutes health ${ }^{1}$. In Ayurvedic classics, various principles have been explained for the maintenance of good health. They include dinacharya (daily regimen), ratricharya (night regimen), and ritucharya (seasonal regimen). Ratricharya deals with the regimen that has to be followed from dusk, through the night up to the dawn which helps in promotion of health and prevention of diseases ${ }^{2}$. Therefore the study is aimed at exploring the various aspects of ratricharya and its role in the maintenance of healthy well-being.

\section{AIMS AND OBJECTIVES}

1. To understand the concept of ratricharya conceptually.

2. To understand the role of the ratricharya in the present era in the promotion of health and prevention of diseases.

\section{MATERIALS AND METHODS}

A. Literature search - Review of Literature regarding the concept of ratricharya is collected from the classical texts of Ayurveda

B. Type of study - Fundamental Study - Literary study on ratricharya and its role in health promotion and disease prevention. 
${ }^{1}$ Dr.Bharath.M.S, International Journal of Ayurvedic \& Herbal Medicine 7(5) Sep.-Oct. 2017 (2856-2860)

\section{RATRI (Night)}

Night is considered to be full of tamas (darkness). It is said to create fear and in the minds of the people. It is said to enhance moha (delusion). It is said to pacify the pitta dosha and it increases the kapha dosha. It also enhances kama (desire) and reduces klama (fatigue) ${ }^{3}$.

\section{JYOTSNA (Moonlight)}

As per the Ayurvedic classics the moonlight that falls on the body has a direct effect on the body and mind. The moonlight is said to be sheeta (cool). It enhances kama (desires). It is said to pacify the pitta dosha and it reduces daha (Burning sensation). Because of its gentle properties, it enhances kapha and vata dosha. It revitalizes the body ${ }^{4}$.

\section{SANDHYACHARYA (Regimens to be followed in dawn and dusk)}

Sandhyacharya is the conjunction of the last part of the day and the first part of the night and also vice versa. Ratricharya begins and ends with Sandhyacharya viz dawn and dusk. This period is considered to be inauspicious and many regimens are contraindicated in this kala (time). We are not supposed to consume any type of ahara (food) at sandhyakala. If we consume food at sandhyakala we may become prey to many diseases and ill health. It is forbidden to have sex in the sandhyakala as it can cause foetal anomalies. Sleeping at the sandhyakala is strictly prohibited as it could lead of loss of wealth and fame. One must also abstain from studying in the sandhyakala as it leads to loss of lifespan ${ }^{5}$.

\section{RATRICHARYA}

The three important aspects of ratricharya are Ahara (Food), Shayana (Sleep), Mithuna (Sexual life).

\section{On Ahara (food)}

As per Ayurvedic classics one must consume food in the first part of night itself so that that the food will be properly digested. The quantity of food consumed should also be of less quantity. Heavy foods which are difficult to digest should be avoided as digestion is weak during the night than in the day ${ }^{6}$. We are not supposed to consume curd at night time as it is abhishyandhi (obstructive) and will cause mandagni (weak digestive fire) and weakens the digestion ${ }^{7}$.

\section{On Sleep}

One must habituate to sleeping at the right place and at the right time. Night sleep nourishes the body and mind whereas staying awake in the night is ruksha (dry) ${ }^{8}$. One must not sleep in a cot which is too tall or too short. One must also abstain from sleeping on a broken cot as it might cause injury to the body and even it may lead to disturbed sleep. One must not sleep under a tree because of the excess carbon di oxide produced by the tree. One must not sleep in curved position as it may lead to spinal deformities and disturbed sleep and hence one must try to sleep in comfortable position ${ }^{9}$. Sleeping at the proper time and proper duration leads to equilibrium of dhatus (tissues) and alleviates lethargy. Adequate night sleep provides nourishment, good complexion, strength, enthusiasm, restores gastric fire and enhances digestion ${ }^{10}$. Staying awake at night is said to be ruksha (dry). Proper night sleep pacifies kapha and destroys poisonous compounds in the body. One must only sleep in proper places and one must not stay in improper places like sacred places, cross roads, gardens, cremation ground etc. during night time ${ }^{11}$.

\section{On Sexual Activities}

Sexual desires are present in all human beings. If one does not indulge in sexual activities appropriately it could lead to many diseases like obesity, Diabetes and general weakness ${ }^{12}$. Sexual regimen should be practiced only on auspicious days and it should not be practiced on specific inauspicious days and time like Sandhyakala or mid-day or mid night ${ }^{13}$. One must indulge in sex in private only after assessing his state of health. 
${ }^{1}$ Dr.Bharath.M.S, International Journal of Ayurvedic \& Herbal Medicine 7(5) Sep.-Oct. 2017 (2856-2860)

\section{Seasonal regimen for Sexual practices}

In winter one can indulge in sexual activities as per desire after taking vrishya (Aphrodisiac) drugs. In sharath ritu (autumn) sex is advised only once in three days. In varsha (rainy) and greeshma ritu (summer) it is advised only once a fortnight ${ }^{14}$.

\section{Post Sexual activities}

One should take bath, Consume milk mixed with sugar, Consume food mixed with sugar, Consume meat and Have good sleep ${ }^{15}$. These diet and sleep is advised to restore the vigour and energy lost during the act of sexual intercourse. By following proper sexual activity as per the regimen mentioned in Ayurvedic classics one could attain long life, delayed ageing, increase in colour and complexion, strength, and good muscle tone $e^{16}$.

\section{Other activities}

\section{Night travel}

In Ayurvedic classics Night travel was forbidden except in case of emergencies probably due to the fear of thieves and wild animals. While travelling one must only go out carrying a head gear stick, Umbrella and foot wear for self-protection ${ }^{17}$.

\section{On study}

One having good health should get up in the morning and do essential routines. One must worship gods, sages, cows, Brahmins, elders, teacher's one must sit on a clean ground and study. Acharyas have said that one can study in the mid-day, afternoon and night without wasting time ${ }^{18}$.

\section{Discussion}

As we are living in the fast forward era of 21 st century, people are preoccupied with their work day and night. Their health is grossly affected. Entire circadian rhythm of the body is affected. By the kind of work people are doing, it is hard to differentiate between day and night. People are not eating food at an appropriate time or are they sleeping adequately hence the end result is the manifestation of so many diseases in the body. In this era the reality is that people are not even aware of any regimen to be followed at night for the promotion of health and well-being. Thus it is equally important to follow the regimen of ratricharya as like dinacharya for a good health. Ratricharya or night regimen is an important concept which was first mentioned in Ayurvedic classical literature. Even in modern literature it is hard to find a single direct reference about the regimen to follow at night for the maintenance of health and well-being although we get scattered yet inconclusive research articles. The major regimen of Ratricharya consists of Food, Sleep and Good Sexual life or Complete Abstinence. Ayurveda says that food should be consumed in the first part of the night. Modern research has proved that heavy food intake during bed time can lead to obesity and other metabolic syndrome. Limiting or avoiding food during night time has been proposed as both a weight loss strategy and approach to improve health and body composition. Negative outcomes have been demonstrated in response to large meals in population that consume a majority of daily food intake during the night. Data is beginning to show that it is better to consume small or low energy foods at night rather than large meals ${ }^{19}$.

As per a study done by Suri \& Pradhan (2010) night snacking syndrome is associated with number of harmful behaviours - Physical and Psychological, including poor dietary quality, and also skipping main meal and nibbling at night may have led to significant change seen in eating pattern and lifestyle of late adolescents. As shown in this study, these fluctuations and changed patterns together could force the youngsters at risk of various chronic illnesses further disrupting their health status and eating attitude causing clinical eating disorders so awareness about healthy eating is important. Night eating syndrome is found to be a syndrome more common in the obese and it can result in further obesity ${ }^{20}$. As per research done by Chaput JP et al, 7-8 hours of sleep is associated with lower prevalence of metabolic syndrome and reduced overall cardio-metabolic risk in adults. Sleeping less than 6 hours per night is associated with an elevated cardio-metabolic risk ${ }^{21}$. As per the research conducted by Grandner et al, (2013), the technology 
${ }^{1}$ Dr.Bharath.M.S, International Journal of Ayurvedic \& Herbal Medicine 7(5) Sep.-Oct. 2017 (2856-2860)

use was associated with sleep patterns, the more type of devices used, the more individuals reported difficulty falling asleep and maintaining sleep especially if use of technology was active. Apart from sleep, healthy sex life is said to be important for the maintenance of good health of both males and females ${ }^{22}$. As per Liu \& Waite (2013) woman are especially vulnerable to cardiovascular problems from poor relationship quality or marital loss ${ }^{23}$. In older ages especially moderate frequency of sex may bring some health benefits but having sex too frequently or extremely high level of physical or emotional enjoyment might be a risk factor for experiencing Cardiovascular diseases over time ${ }^{24}$. The role of celibacy in the maintenance of good health is not much known. Further research is needed to establish the same Thus it is important to follow various rules of rathricharya appropriately as said in Ayurveda classics for the maintenance of health and well-being.

\section{Conclusion}

To achieve the better health/positive health and prevent diseases one has to practice the principles mentioned in Swasthavritta like the concept of ratricharya. It is said that one who does not resort to dinadi dinacharya (daily regimen) including sandhyacharya (evening regimens) and ratricharya (night regimen) will fall prey to diseases. Thus effort should be made to practice the same on a daily basis so as to maintain a good health. Thus it is inevitable to say that we have to practice dinacharya and ratricharya continuously to attain the highest state of well-being especially people who are working in IT sector can modify their lifestyle accordingly.

\section{References}

1. Park K. Park's Textbook of Preventive and Social medicine. $21^{\text {st }}$ edition. Bhanot publishers. Jabalpur. Page no 14-15.

2. Shastry lakshmipathi, Yogaratnakara, Poorvarda, Rathricharya vidhi, Chaukambha orientalia, first reprint 2010 page no 82

3. Shastry lakshmipathi, Yogaratnakara, Poorvardha, Rathricharya vidhi, Chaukambha orientalia, first reprint 2010 page no 82

4. Shastry lakshmipathi, Yogaratnakara, Poorvardha, Rathricharya vidhi, Chaukambha orientalia, first reprint 2010 page no 82

5. Shastry lakshmipathi, Yogaratnakara, Poorvardha, Rathricharya vidhi, Chaukambha orientalia, first reprint 2010 page no 82

6. Shastry lakshmipathi, Yogaratnakara, Poorvardha, Rathricharyavidhi, Chaukambha orientalia, first reprint 2010 page no 82-83

7. Sharma PV. Charaka Samhitha, Chaukambha orientalia, first reprint, 2010, Chapter 7, page no 53

8. Sharma PV.Charaka Samhitha, Chaukambha orientalia, first reprint, 2010, Chapter 21, page no 147

9. Sharma PV.Charaka Samhitha, Chaukambha orientalia, first reprint, 2010, Chapter 8, page no 59

10. Sharma PV.Charaka Samhitha, Chaukambha orientalia, first reprint, 2010, Chapter 21, page no 147

11. Sharma PV.Charaka Samhitha, Chaukambha orientalia, first reprint, 2010, Chapter 8, page no 59

12. Shastry lakshmipathi, Yogaratnakara, Poorvardha, Rathricharya vidhi, Chaukambha orientalia, first reprint 2010 page no 63

13. Shastry lakshmipathi, Yogaratnakara, Poorvardha, Rathricharya vidhi, Chaukambha orientalia, first reprint 2010 page no 62

14. Shastry lakshmipathi, Yogaratnakara, Poorvardha, Rathricharya vidhi, Chaukambha orientalia, first reprint 2010 page no 64

15. Murthy Sreekantha, Bhavaprakasha, Poorvardha, Chowkambha Krishnadas academy first reprint 2011 page 112

16. Murthy Sreekantha, Bhavaprakasha, Poorvardha, Chowkambha Krishnadas academy first reprint 2011 page 113

17. Sharma PV, Charaka Samhitha, Volume one, Chaukambha orientalia, first reprint 2010 page no 53

18. Sharma PV, Charaka Samhitha, Volume one, Chaukambha orientalia, first reprint 2010 page no 54

19. Amber w Kinsey, Michael T Ormsbee, The Health Impact of Night Time Eating, old and new perspectives, Nutrients J, 2015 Apr7(4) 2648-2662. 
${ }^{1}$ Dr.Bharath.M.S, International Journal of Ayurvedic \& Herbal Medicine 7(5) Sep.-Oct. 2017 (2856-2860)

20. Suri S \& Pradhan R, Assessment of Night Eating Syndrome Among late Adolescents, Indian J Psychol Med, 2010, Jan-Jun 32(1) 71-72.

21. Chaput J.P et al, Seven to Eight Hours of Sleep a night is associated with a lower Prevalence of Metabolic Syndrome and Reduced Overall Cardiometabolic risk in Adults, PLos one J, 2013, 8(9)

22. Grandner MA, Gallagal R, Goonarathne NS, Use of Technology at Night- Impact of Sleep and Health. J Clinical Sleep Medicine.2013 9(12) 1301-1302

23. Liu hui, Walter linde, Bad Marriage, Broken Heart, Age and gender differences in the link between Marital quality and cardiovascular risk among Older adults, J Health and Social Behaviour,2014 55(4) 40-43

24. Zhang zhenmai, Hayward Mark D, Gender, the Marital life course and cardiovascular health in Late Mid-life, Journal of Marriage \& Family 2006 68(3), 639-652 